Научная статья

УДК 599.742.1

DOI: $10.18101 / 2542-0623-2021-4-45-64$

\title{
МОРФОФИЗИОЛОГИЧЕСКАЯ ИЗМЕНЧИВОСТЬ МЕЛКИХ МЛЕКОПИТАЮЩИХ ХИНДИКТИГ-ХОЛЬСКОЙ ВПАДИНЫ
}

\author{
С. О. Ондар, С. Н. Кирпотин, Н. И. Путинцев, А. О. Ховалыг, \\ Б. С. Монгуш, О. Ч. Ойдупаа, А. В. Куулар
}

\section{(C) Ондар Сергей Октяевич}

доктор биологических наук, главный научный сотрудник, заведующий научной лабораторией экологических исследований Тувинский государственный университет Россия, 667000 г. Кызыл, ул. Ленина, 36 ondar17@yandex.ru

\section{(C) Кирпотин Сергей Николаевич} доктор биологических наук, профессор, главный научный сотрудник, Тувинский государственный университет Россия, 667000, г. Кызыл, ул. Ленина, 36 директор центра «БиоКлимЛанд», Национальный исследовательский Томский государственный университет Россия, 634050, г. Томск, пр. Ленина, 36 kirp@mail.tsu.ru

(C) Путинцев Николай Иванович младший научный сотрудник, заведующий экологическим музеем, Тувинский государственный университет Россия, 667000, г. Кызыл, ул. Ленина, 36 bkafedra@list.ru

(c) Ховалыг Алдынай Олеговна кандидат географических наук, доцент кафедры географии и туризма Тувинский государственный университет Россия, 667000, г. Кызыл, ул. Ленина, 36 магистрант, Национальный исследовательский Томский государственный университет Россия, 634050, г. Томск, пр. Ленина, 36 aldyn@mail.ru

\section{(C) Ойдупаа Орлан Чуккаевич} кандидат биологических наук, доцент кафедры биологии и экологии, Тувинский государственный университет Россия, 667000, г. Кызыл, ул. Ленина, 36 nalro@mail.ru 


\section{(ㄱ) Монгуш Байлак Суворовна}

аспирант,

Тувинский государственный университет

Россия, 667000 г. Кызыл, ул. Ленина, 36

baiarnasmo@mail.ru

\section{(C) Куулар Айвар Валентинович}

аспирант, методист Тувинского научного центра, Тувинский государственный университет Россия, 667000 г. Кызыл, ул. Ленина, 36 mackenza@mail.ru

Аннотация. Представлены результаты исследования морфофизиологической изменчивости мелких млекопитающих Хиндиктиг-Хольской впадины высокогорного массива Монгун-Тайга (юго-западная Тува). Всего исследовано 224 взрослых особей трех массовых видов родов Lasiopodomus, Microtus и Alticola. Сравнительная характеристика экстерьерных пластических и интерьерных морфофизиологических признаков популяций узкочерепной полевки (L. gregalis), полевки-экономки (A. oеconomus) и плоскочерепной полевки (A. strelzovii), обитающих на идентичных биотопах острова озера Хиндиктиг-Холь и на материке, показали, что комплекс факторов и авторегуляторные популяционные механизмы отличаются. Морфофункциональные адаптации мелких млекопитающих островных и материковых популяций носят сложный и неоднозначный характер. Установлено, что морфофизиологические параметры популяций видов имеют изменчивость в сторону снижения массы и длины тела и увеличению индексов внутренних органов на материковой части, а на острове у популяций тех же видов проявляются противоположные отношения - увеличение массы сопряжено уменьшением индексов внутренних органов. Биогеохимические исследования почв и растительного покрова основных биотопов мелких млекопитающих позволило выявить высокие значения содержания некоторых тяжелых металлов и на острове и на материке, что может являться фактором, определяющим направления адаптационных возможностей организмов. Морфофизиологическую изменчивость, проявляющаяся у материковых и островных популяций изученных видов, следует рассматривать как случаи генетической ассимиляции морфозов, адаптивных к физико-химическим условиям района исследований.

Ключевые слова: Lasiopodomus gregalis, Alexandromys oeconomus, Alticola strelzovii, экстерьерные и интерьерные биологические признаки, островные и материковые популяции, морфофизиологическая изменчивость.

Благодарности. Исследование выполнено за счет гранта Российского научного фонда проект № 20-67-46018 «Климатически и антропогенно обусловленные изменения уязвимых экосистем Тувы».

\section{Для цитирования}

Морфофизиологическая изменчивость мелких млекопитающих Хиндиктиг-Хольской впадины / С. О. Ондар, С. Н. Кирпотин, Н. И. Путинцев, А. О. Ховалыг, Б. С. Монгуш, О. Ч. Ойдупаа, А. В. Куулар // Природа Внутренней Азии. Nature of Inner Asia. 2021. № 4(19). C. 45-64. DOI: 10.18101/2542-0623-2021-4-45-64 


\section{Введение}

Высокогорные озерные системы могут функционировать по своим особым закономерностям. Они могут проявляться в параметрах гео- и биогеохимических, гидрологических, гидробиологических, гидрохимических процессов, биогенетических компонентов, направлениях структурной и функциональной организации биологических систем и ландшафтов.

В таких системах в условиях сложного горного рельефа, биогенетической и ландшафтной мозаики могут сформироваться особые геохимические провинции. Наличие постоянных ледников и снежников на высотах, близких к 4000 м над уровнем моря на горных системах Внутренней Азии, подвергающихся в последние годы интенсивному таянию, определяют высокую динамичность проявления многих физико-химических и биологических процессов.

Исследования на мелких млекопитающих, обитающих на таких территориях, могут послужить отправной точкой для экстраполяции данных наблюдений на физиологию человека. Структурно-функциональные оценки состояния интерьерных органов рассматриваются многими авторами как неспецифические интегральные показатели биологического действия на организм различных неблагоприятных факторов [1], формирующих устойчивые морфофизиологические адаптации.

Внешнее воздействие может дестабилизировать онтогенез, что приводит к появлению разнообразных «морфозов» - аномальных фенотипов (реализуются доселе скрытые альтернативные пути развития). Если какой-то из аномальных фенотипов окажется «удачным» (адаптивным в новых условиях), отбор в дальнейшем будет закреплять мутации, повышающие вероятность реализации именно этого альтернативного пути развития. В результате аномалия станет новой нормой и/или происходит «генетическая ассимиляция морфозов» [2].

В научной литературе практически отсутствуют исследования в этом направлении. Возможно, проявляющиеся у островных и материковых популяций необходимо рассматривать как адаптации, сформированные в рамках эпигенетических траекторий развития организма.

Изолированный массив Монгун-Тайга расположен в резкоконтинентальной аридной провинции в центре Алтае-Саянской горной страны и отделен от западных и северо-западных территорий с континентальным климатом Шапшальским хребтом и хр. Цаган-Шибету. Монгун-Тайга характеризуется значительным ландшафтным своеобразием. В физико-географическом отношении массив расположен на стыке широтных зон степей и полупустынь и долготно-климатических секторов с континентальным и резко-континентальным климатом, что на фоне значительного перепада высот в сильно расчлененном высокогорном рельефе и на разноуровневых поверхностях выравнивания создает мозаичное многообразие ландшафтов.

Растительный покров района исследований представлен редкими лиственничными лесами на северных склонах, тундровыми сообществами, а в южной экспозиции склонах представлены степные сообщества с Festuca squamulosa, F. kryloviana, Setaria viridis, Poa attenuata и др.

Основу криоксерофильных высокогорных флористических комплексов котловины составляют Sibbaldia tetrandra, Eritrichium villosum, Chamaerhodos altaica, 
Saxifraga melaleuca, Crepis chrysanta. Характерной особенностью их структуры является сочетание высокогорных тундровых и степных видов.

Криогигрофильные флористические комплексы представлены различными типами тундр (мохово-ерниковыми и травяными), приуроченными к относительно влажным, связанным с сезонной деградацией многолетней мерзлоты, биотопам.

Разнотравные мезофильные луга распространены в локальных увлажненных понижениях и не образуют сплошного пояса, их расположение скорее мозаичное.

Криопетрофитные флористические комплексы поднимаются до высоты 3400 м, откуда начинается гольцовая зона с фрагментарным растительным покровом в прогреваемых слонах. Альпийские луга (2 400-3 000 м) фрагментарно распространены на бурозёмах в основном приурочены к прогреваемым склонам южной экспозиции. Злаково-осоково-разнотравные луга распространены преимущественно в высотах 2000-2800 м и характеризуются большим разнообразием разнотравья и злаков из следующих видов: Festuca ovina, F. kryloviana, Poa altaica, Dracocephalum grandiflorum, Campanula rotundifolia, Potentilla gelida и др., а также наличием тундровых и степных кустарничков с участием Betula rotundifolia, Juniperus pseudosabina, Spiraea alpina, S. media, Salix reticulate, S.glauca.

В качестве основного объекта исследований выбраны массовые виды мелких млекопитающих, традиционно являющиеся модельным объектом экологических исследований теоретического и прикладного характера.

Изучение биоценотических, популяционных и морфофизиологических параметров мелких млекопитающих проводилось в Хиндиктиг-Хольской впадине 2017-2018 гг., расположенной в западной части массива на высотах более 2300 м над уровнем моря $\left(50^{\circ} 22^{\prime} 80^{\prime \prime} \mathrm{N} ; 89^{\circ} 56^{\prime} 28^{\prime \prime} \mathrm{E}\right)$. С озера берет начало крупная река Моген-Бурен, впадающая в озеро Ачит-Нуур, входящая в бассейновую систему бессточных котловин Больших озер Монголии.

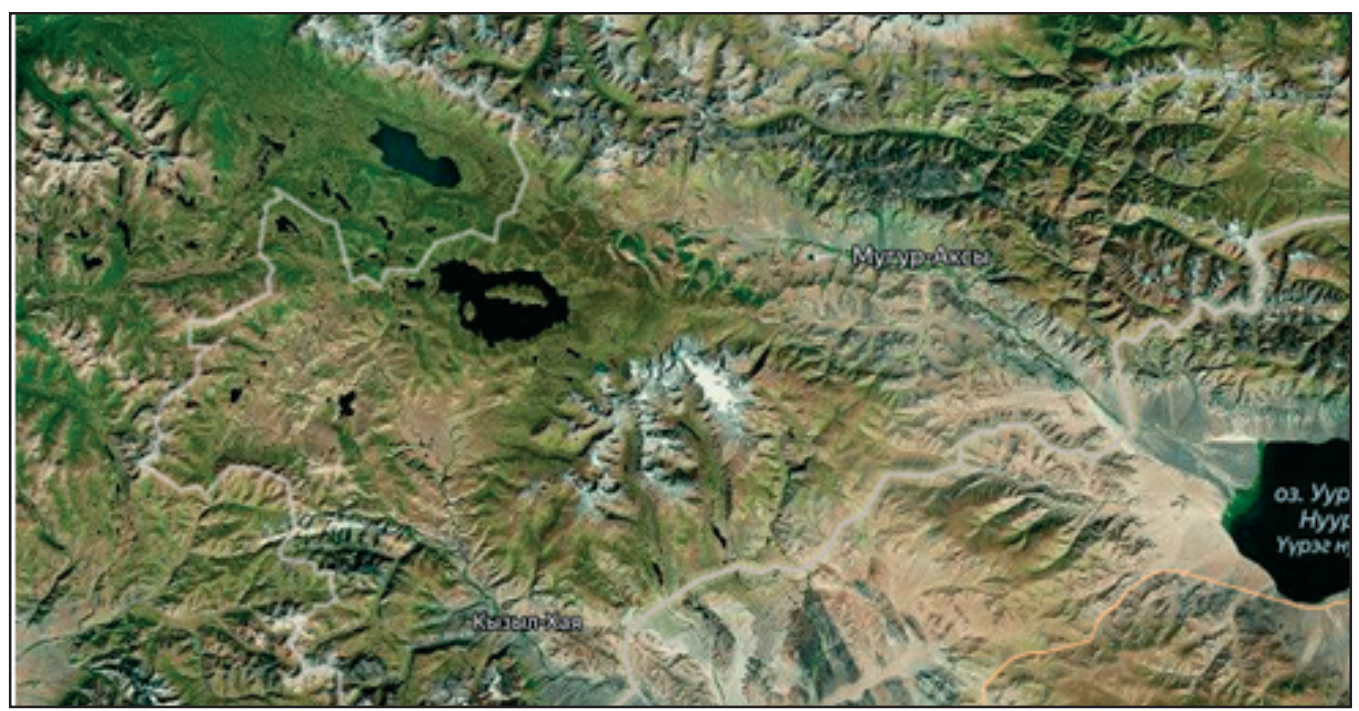

Puc. 1. Спутниковый снимок местоположения Хиндиктиг-Хольской впадины (из http://russia-karta.ru.htm).

Стрелками показаны основные точки исследований 
Морено-подпрудное озеро Хиндиктиг-Холь $\left(50^{\circ} 21^{\prime} 17^{\prime \prime} \mathrm{N}\right.$; 8949'44"Е) площа-

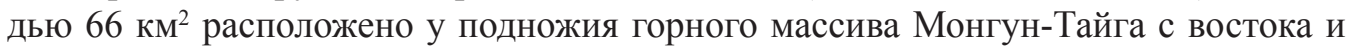
отрогов Шапшальского хребта с запада и с севера, на высоте над уровнем моря 2305 м. В центральной части озера имеются два острова, образованных выходами коренных пород (рис. 1). Перепад высот на крупном острове площадью около

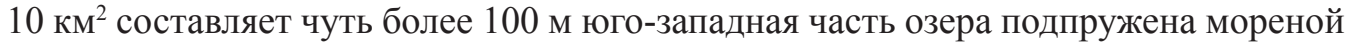
древнего ледника. Морено-подпрудные озера в основном, связаны со стадиальными колебаниями ледников, начиная с ранневюрмского оледенения [3].

Цель настоящей работы заключается в сравнительном изучении морфофизиологических адаптаций островных и материковых популяций мелких млекопитающих к автохтонным биогеохимическим процессам, контролирующим трансформацию депонированного органического углерода и связанных микроэлементов в природной среде [4].

\section{Материал и методики исследований}

Мелкие млекопитающие отлавливались при помощи давилок и ловчих канавок. Отработано 1250 ловушко-суток. Для морфофизиологической оценки параметров были использованы 224 взрослых (половозрелых) особей трех массовых видов мелких млекопитающих - представителей родов Lasiopodomus, Alexandromys и Alticola: узкочерепная полевка (Lasiopodomus gregalis), полевка-экономка (Alexandromys oеconomus) и плоскочерепная горная полевка (Alticola strelzovii), заселяющих сходные биотопы изолированного острова озера Хиндиктиг-Холь и материковой части Хиндиктиг-Хольской впадины, являвшихся доминантами в сообществах мелких млекопитающих. Возраст зверьков определялись по массе тела, состоянию зубной и генеративной систем [5].

Измерения морфометрических индикаторов осуществлялась по общепринятым методикам [6-12]. В качестве экстерьерных признаков использовались масса тела (M), длина тела (L), длина хвоста (C), длина ступни (Pl) и длина уха (A), а морфофизиологических (интерьерных) признаков - размеры органов, функции которых непосредственно связаны с обменом веществ и энергии в организме сердца, печени, почек. Индекс органа определялся как отношение массы исследуемого органа к массе тела. Определялись также среднеквадратическое отклонение, ошибка средней и достоверность различий сравниваемых индексов. Для статистической обработки массового материала использованы традиционные подходы анализа и программный пакет Statistica 6.0.

Биогеохимическую ситуацию района исследования оценивали по уровням содержания следующих химических элементов: $\mathrm{V}, \mathrm{Cr}, \mathrm{Mn}, \mathrm{Co}, \mathrm{Ni}, \mathrm{Cu}, \mathrm{Zn}, \mathrm{As}$, $\mathrm{Sr}, \mathrm{Pb}, \mathrm{Fe}, \mathrm{Br}, \mathrm{Ba}, \mathrm{Ti}$ в почве и растительном покрове исследуемой территории. Экологическое состояние растений диагностировалось по отношениям $\mathrm{Fe} / \mathrm{Mn}$ и $\mathrm{Pb} / \mathrm{Mn}$. Отношение $\mathrm{Fe} / \mathrm{Mn}$ является одним из наиболее информативных показателей процессов фотосинтеза, a $\mathrm{Pb} / \mathrm{Mn}$ характеризует соотношение токсичных и биофильных элементов [13]. Качественные химические анализы проведены в физикохимической лаборатории Центра коллективного пользования Тувинского государственного университета рентгенофлуоресцентным методом с применением аппаратов рентгеновских для спектрального анализа СПЕКТРОСКАН МАКС. 


\section{Результаты исследования и обсуждение}

К настоящему времени можно считать твердо установленным правило обратной зависимости относительной величины органов от размеров тела [14-20]. Вместе с тем многочисленные исключения из этого правила указывают на характерные морфофизиологические перестройки, не связанные с «законом поверхности», а обусловлены корректирующим действием экологических факторов и самими адаптивными реакциями животных. С этих позиций анализ подобных «исключений» дает ценнейший материал для изучения морфофизиологических механизмов приспособления и адаптивных преобразований популяций и видов, способствует выявлению их экологической специфики и представляет поэтому особый интерес $[2,21,23]$.

Проведенные исследования позволяют говорить об отличиях в проявлении интерьерных и экстерьерных признаков изученных видов (Lasiopodomus gregalis, Alexandromys oeconomus, Alticola strelzovii) из двух изученных групп популяций островных и материковых. У животных из материковых биотопов наблюдается увеличение общебиологических параметров. Так средняя масса тела у половозрелых самцов Lasiopodomus gregalis на материке в среднем меньше массы тела особей островной популяции в 2,4 раза и средняя длина тела особей из материка меньше средних значений массы тела особей островной популяции в 1,3-1,4 раза (табл. 1). Такая закономерность проявляется также в отношении самок материковой популяции Alexandromys oеconomus, у которых отмечается уменьшение массы тела в 0,7 раза (табл. 2). Интересно, что для самцов сравниваемых популяций характерна значимая обратная зависимость. Из таблицы 2 видно, что средние масса и длина тела у представителей материковых популяций заметно больше по сравнению с показателями самцов островной популяции полевки-экономки. У Alticola strelzovii обеих полов островных и материковых популяций достоверных различий средних значений массы тела не отмечается, а длина тела самцов материковых популяций меньше таковых у самцов островной популяции.

Изменений индексов пластических признаков в результате исследований не установлено за исключением длины уха особей из островной популяции горной полевки, у которых отмечается устойчивое уменьшение признака. У узкочерепной полевки и полевки-экономки величины индексов длины хвоста, длины ступни и высоты уха имеют некоторые отличия у животных из двух изученных местообитаний независимо от пола (табл. 1, 2).

Таблица 1

Сравнительная характеристика экстерьерных пластических признаков популяций узкочерепной полевки (L. gregalis)

\begin{tabular}{|c|c|c|c|c|c|}
\hline \multirow{2}{*}{$\begin{array}{l}\text { Экстерьерные } \\
\text { пластические } \\
\text { признаки }\end{array}$} & \multirow{2}{*}{$\begin{array}{c}\text { Пол } \\
(\widehat{\jmath}, \text {, }) \text { и }(\mathrm{n})\end{array}$} & \multirow{2}{*}{$\begin{array}{c}\text { Материк } \\
(\mathrm{M} \pm \mathrm{m})\end{array}$} & \multirow{2}{*}{$\begin{array}{c}\text { Остров } \\
(\mathrm{M} \pm \mathrm{m})\end{array}$} & Материк & Остров \\
\hline & & & & Lim & Lim \\
\hline 1 & 2 & 3 & 4 & 5 & 6 \\
\hline \multirow{2}{*}{ Масса тела, г (M \pm m) } & $\widehat{O}\left(n_{1}=21 ; n_{2}=18\right)$ & $14,9 \pm 0,8$ & $36,2 \pm 3,4$ & $16,1-13,5$ & $41,5-30,0$ \\
\hline & $q\left(\mathrm{n}_{1}=18 ; \mathrm{n}_{2}=19\right)$ & $18,7 \pm 6,2$ & $36,7 \pm 3,5$ & $28,1-14,2$ & $41,5-30,9$ \\
\hline
\end{tabular}


Продолюение табл. 1

\begin{tabular}{|c|c|c|c|c|c|}
\hline 1 & 2 & 3 & 4 & 5 & 6 \\
\hline \multirow{2}{*}{ Длина тела, мм (L) } & $\widehat{\partial}\left(\mathrm{n}_{1}=21 ; \mathrm{n}_{2}=18\right)$ & $87,5 \pm 4,32$ & $120,4 \pm 3,4$ & $91-76$ & $123,2-114,7$ \\
\hline & $+\left(\mathrm{n}_{1}=18 ; \mathrm{n}_{2}=19\right)$ & $92,1 \pm 8,2$ & $119,8 \pm 5,4$ & $105-83$ & $131,2-114,7$ \\
\hline \multirow{2}{*}{ Длина хвоста, мм (С) } & $\hat{O}\left(n_{1}=21 ; n_{2}=18\right)$ & $22,8 \pm 1,9$ & $31,0 \pm 2,1$ & $26-21,5$ & $36,2-28,04$ \\
\hline & $q\left(\mathrm{n}_{1}=18 ; \mathrm{n}_{2}=19\right)$ & $24,3 \pm 2,1$ & $29,4 \pm 1,7$ & $27,1-22,5$ & $33,8-27,3$ \\
\hline \multirow{2}{*}{ Длина ступни, мм (PI) } & $\hat{O}\left(\mathrm{n}_{1}=21 ; \mathrm{n}_{2}=18\right)$ & $15,4 \pm 0,7$ & $15,3 \pm 0,4$ & $16,3-14,0$ & $15,7-14,4$ \\
\hline & $q\left(\mathrm{n}_{1}=18 ; \mathrm{n}_{2}=19\right)$ & $15,3 \pm 0,4$ & $15,1 \pm 0,4$ & $15,7-14,4$ & $15,8-14,7$ \\
\hline \multirow{2}{*}{ Длина уха, мм (А) } & $\hat{O}\left(n_{1}=21 ; n_{2}=18\right)$ & $9,8 \pm 0,84$ & $9,8 \pm 1,3$ & $11,4-8,5$ & $11,1-8,0$ \\
\hline & $+\left(\mathrm{n}_{1}=18 ; \mathrm{n}_{2}=19\right)$ & $9,8 \pm 1,3$ & $10,8 \pm 1,94$ & $11,1-8,0$ & $15,5-9,6$ \\
\hline
\end{tabular}

Таблицьа 2

Сравнительная характеристика экстерьерных пластических признаков популяций полевки-экономки (A. oeconomus)

\begin{tabular}{|c|c|c|c|c|c|}
\hline \multirow{2}{*}{$\begin{array}{c}\text { Экстерьерные } \\
\text { пластические } \\
\text { признаки } \\
\end{array}$} & \multirow{2}{*}{$\begin{array}{c}\text { Пол } \\
(\lesssim,+) \text { и (n) }\end{array}$} & \multirow{2}{*}{$\begin{array}{c}\text { Материк } \\
(\mathrm{M} \pm \mathrm{m})\end{array}$} & \multirow{2}{*}{$\begin{array}{c}\text { Остров } \\
(\mathrm{M} \pm \mathrm{m})\end{array}$} & \multirow{2}{*}{\begin{tabular}{|c|} 
Материк \\
$\operatorname{Lim}$ \\
\end{tabular}} & \multirow{2}{*}{$\begin{array}{c}\text { Остров } \\
\operatorname{Lim}\end{array}$} \\
\hline & & & & & \\
\hline 1 & 2 & 3 & 4 & 5 & 6 \\
\hline \multirow{2}{*}{ Масса тела, г (M \pm m) } & $\hat{O}\left(\mathrm{n}_{1}=19 ; \mathrm{n}_{2}=15\right)$ & $29,1 \pm 14,4$ & $25,8 \pm 11,9$ & $47,3-14,7$ & $43,7-29,3$ \\
\hline & $q\left(\mathrm{n}_{1}=17 ; \mathrm{n}_{2}=18\right)$ & $32,1 \pm 9,9$ & $43,6 \pm 3,4$ & $50,2-20,0$ & $46,9-40,1$ \\
\hline \multirow{2}{*}{ Длина тела, мм (L) } & $\hat{O}\left(\mathrm{n}_{1}=19 ; \mathrm{n}_{2}=15\right)$ & $106,7 \pm 18,7$ & $102,1 \pm 16,3$ & $134-88$ & $126,3-93$ \\
\hline & $q\left(\mathrm{n}_{1}=17 ; \mathrm{n}_{2}=18\right)$ & $108,8 \pm 12,1$ & $127,8 \pm 4,2$ & $133-96$ & $132,6-126,5$ \\
\hline \multirow{2}{*}{ Длина хвоста, мм (С) } & $\hat{O}\left(n_{1}=19 ; n_{2}=15\right)$ & $35,9 \pm 8,7$ & $33,1 \pm 2,2$ & $48-24$ & $36,3-31,6$ \\
\hline & $q\left(\mathrm{n}_{1}=17 ; \mathrm{n}_{2}=18\right)$ & $37,6 \pm 8,8$ & $38,3 \pm 10,9$ & $52,4-26$ & $50,8-31,4$ \\
\hline \multirow{2}{*}{ Длина ступни, мм (PI) } & $\hat{O}\left(\mathrm{n}_{1}=19 ; \mathrm{n}_{2}=15\right)$ & $16,9 \pm 1,23$ & $16,7 \pm 0,7$ & $18,8-15,1$ & $17,2-15,7$ \\
\hline & $q\left(\mathrm{n}_{1}=17 ; \mathrm{n}_{2}=18\right)$ & $17,1 \pm 2,3$ & $16,4 \pm 1,2$ & $19,2-15,2$ & $17,8-15,7$ \\
\hline \multirow{2}{*}{ Длина уха, мм (А) } & $\hat{O}\left(n_{1}=19 ; n_{2}=15\right)$ & $11,7 \pm 1,7$ & $13,1 \pm 3,1$ & $12,8-9,3$ & $17,7-11,2$ \\
\hline & $q\left(\mathrm{n}_{1}=17 ; \mathrm{n}_{2}=18\right)$ & $12,3 \pm 2,5$ & $11,4 \pm 1,04$ & $16,0-8,7$ & $12,4-10,4$ \\
\hline
\end{tabular}

Таблицьа 3

Сравнительная характеристика экстерьерных пластических признаков популяций плоскочерепной полевки (A. strelzovii)

\begin{tabular}{|c|c|c|c|c|c|}
\hline \multirow{2}{*}{$\begin{array}{c}\text { Экстерьерные } \\
\text { пластические } \\
\text { признаки }\end{array}$} & \multirow{2}{*}{$\begin{array}{c}\text { Пол } \\
(\lesssim,+) \text { и (n) }\end{array}$} & \multirow{2}{*}{\begin{tabular}{|c|} 
Материк \\
$(\mathrm{M} \pm \mathrm{m})$
\end{tabular}} & \multirow{2}{*}{$\begin{array}{c}\text { Остров } \\
(\mathrm{M} \pm \mathrm{m})\end{array}$} & \multirow{2}{*}{\begin{tabular}{|c|} 
Материк \\
$\operatorname{Lim}$ \\
\end{tabular}} & \multirow{2}{*}{$\begin{array}{c}\text { Остров } \\
\operatorname{Lim}\end{array}$} \\
\hline & & & & & \\
\hline 1 & 2 & 3 & 4 & 5 & 6 \\
\hline \multirow{2}{*}{ 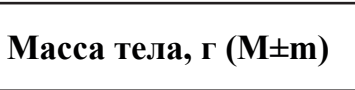 } & $\hat{O}\left(\mathrm{n}_{1}=22 ; \mathrm{n}_{2}=19\right)$ & $26,1 \pm 6,1$ & $25,4 \pm 2,5$ & $43,2-21,1$ & $28,7-28$ \\
\hline & $q\left(n_{1}=20 ; n_{2}=18\right)$ & $30,9 \pm 8,8$ & $30,8 \pm 8,8$ & $51,8-23,9$ & $46,1-23,9$ \\
\hline \multirow{2}{*}{ Длина тела, мм (L) } & $\delta\left(n_{1}=22 ; n_{2}=19\right)$ & $99,5 \pm 5,4$ & $104,9 \pm 6,7$ & $114-93$ & $109,2-95,3$ \\
\hline & $q\left(n_{1}=20 ; n_{2}=18\right)$ & $105,1 \pm 8,4$ & $105,1 \pm 8,4$ & $124-98$ & $124-98$ \\
\hline \multirow{2}{*}{ Длина хвоста, мм (C) } & $\hat{O}\left(\mathrm{n}_{1}=22 ; \mathrm{n}_{2}=19\right)$ & $41,4 \pm 3,2$ & $40,0 \pm 2,6$ & $43-34$ & $45,4-38,1$ \\
\hline & $q\left(\mathrm{n}_{1}=20 ; \mathrm{n}_{2}=18\right)$ & $41,2 \pm 6,0$ & $41,2 \pm 6,0$ & $48,5-32$ & $48,5-25,0$ \\
\hline \multirow{2}{*}{ Длина ступни, мм (PI) } & $\widehat{O}\left(\mathrm{n}_{1}=22 ; \mathrm{n}_{2}=19\right)$ & $20,8 \pm 0,81$ & $20,4 \pm 0,8$ & $22,8-19,8$ & $21,2-20,0$ \\
\hline & $q\left(n_{1}=20 ; n_{2}=18\right)$ & $20,1 \pm 1,4$ & $20,0 \pm 1,4$ & $21-19,3$ & $21,4-19$ \\
\hline \multirow{2}{*}{ Длина уха, мм (А) } & $\widehat{O}\left(\mathrm{n}_{1}=22 ; \mathrm{n}_{2}=19\right)$ & $17,5 \pm 1,3$ & $14,5 \pm 1,2$ & $20,0-17,3$ & $16,4-13,0$ \\
\hline & $q\left(n_{1}=20 ; n_{2}=18\right)$ & $19,1 \pm 1,4$ & $16,1 \pm 1,9$ & $16,8-12$ & $18,0-12$ \\
\hline
\end{tabular}


Сравнительная характеристика экстерьерных пластических и интерьерных морфофизиологических признаков популяций узкочерепной полевки (L. gregalis), полевки-экономки (A. oеconomus) и плоскочерепной полевки (A. strelzovii) в Хиндиктиг-Хольской впадине, обитающих на идентичных биотопах острова озера Хиндиктиг-Холь и на материке, представленные в таблицах (4-6), свидетельствуют о том, что комплекс факторов и авторегуляторные популяционные механизмы, действующие на острове и на материке, отличаются. Они оказывают влияние не только на структуру и функционирование популяций и сообществ, но и на физиологические процессы самцов и самок.

Средние значения массы печени, почек и сердца имеют достоверные различия у особей обеих полов островных и материковых популяций узкочерепной полевки, заселяющей различные биотопы - открытые остепненные луга на склонах южной экспозиции, увлажненные луга на береговой линии, закустаренные криоксерофильные биотопы на границе ерниковой тундры. Сравнение показало, что у L. gregalis обеих полов, обитающих на материковых биотопах, происходит достоверное увеличение некоторых морфофизиологических индикаторов (табл. 2): увеличиваются массы печени (1,2 раза) почек (в 10,7 раза) и сердца (в 8,3 раз).

Таблий 4

Сравнительная характеристика интерьерных морфофизиологических признаков популяций узкочерепной полевки (L. gregalis)

\begin{tabular}{|c|c|c|c|c|}
\hline Индекс органа & $\begin{array}{l}\text { Пол особей } \\
(\hat{0}, q) \text { и }(\mathrm{n})\end{array}$ & Материк & Остров & $\begin{array}{c}\text { Достоверность } \\
\text { различий (t) }\end{array}$ \\
\hline 1 & 2 & 3 & 4 & 5 \\
\hline \multirow{2}{*}{ Индекс печени } & $\hat{O}\left(\mathrm{n}_{1}=21 ; \mathrm{n}_{2}=18\right)$ & $12,08 \pm 0,16$ & $3,9 \pm 0,4$ & 0,6 \\
\hline & P $\left(\mathrm{n}_{1}=18 ; \mathrm{n}_{2}=19\right)$ & $9,6 \pm 3,4$ & $3,6 \pm 0,8$ & 0,58 \\
\hline \multirow{2}{*}{ Индекс почки } & $\hat{O}\left(\mathrm{n}_{1}=21 ; \mathrm{n}_{2}=18\right)$ & $14,7 \pm 0,13$ & $0,60 \pm 0,1$ & 1,46 \\
\hline & $q\left(\mathrm{n}_{1}=18 ; \mathrm{n}_{2}=19\right)$ & $11,9 \pm 0,1$ & $0,46 \pm 0,03$ & 0,95 \\
\hline \multirow{2}{*}{ Индекс сердца } & $\partial\left(n_{1}=21 ; n_{2}=18\right)$ & $12,3 \pm 3,1$ & $0,60 \pm 0,11$ & 0,95 \\
\hline & P $\left(\mathrm{n}_{1}=18 ; \mathrm{n}_{2}=19\right)$ & $6,4 \pm 0,14$ & $0,5 \pm 0,03$ & 0,92 \\
\hline
\end{tabular}

$\mathrm{n}_{1}$ - объем выборки из материковых популяций; $\mathrm{n}_{2}$ - объем выборки из островных популяций

Таблииа 5

Сравнительная характеристика интерьерных морфофизиологических признаков популяций полевки-экономки (A. oеconomus)

\begin{tabular}{|c|c|c|c|c|}
\hline Индекс органа & $\begin{array}{c}\text { Пол } \\
(\hat{\jmath},+\circ) \text { и (n) }\end{array}$ & Материк & Остров & $\begin{array}{c}\text { Достоверность } \\
\text { различий (t) }\end{array}$ \\
\hline 1 & 2 & 3 & 4 & 5 \\
\hline \multirow{2}{*}{ Индекс печени } & $\hat{O}\left(\mathrm{n}_{1}=19 ; \mathrm{n}_{2}=15\right)$ & $7,2 \pm 0,52$ & $3,6 \pm 0,76$ & 0,5 \\
\hline & $q\left(\mathrm{n}_{1}=17 ; \mathrm{n}_{2}=18\right)$ & $7,1 \pm 0,43$ & $4,7 \pm 0,21$ & 0,28 \\
\hline \multirow{2}{*}{ Индекс почки } & $\hat{O}\left(\mathrm{n}_{1}=19 ; \mathrm{n}_{2}=15\right)$ & $3,6 \pm 1,08$ & $0,46 \pm 0,05$ & 0,87 \\
\hline & $q\left(\mathrm{n}_{1}=17 ; \mathrm{n}_{2}=18\right)$ & $1,09 \pm 0,89$ & $0,57 \pm 0,05$ & 0,43 \\
\hline \multirow{2}{*}{ Индекс сердца } & $\lambda\left(n_{1}=19 ; n_{2}=15\right)$ & $3,5 \pm 0,76$ & $0,50 \pm 0,08$ & 0,85 \\
\hline & $q\left(\mathrm{n}_{1}=17 ; \mathrm{n}_{2}=18\right)$ & $1,27 \pm 0,44$ & $0,64 \pm 0,12$ & 0,31 \\
\hline
\end{tabular}

$\mathrm{n}_{1}$ - объем выборки из материковых популяций; $\mathrm{n}_{2}$ - объем выборки из островных популяций 
Сравнительная характеристика интерьерных морфофизиологических признаков популяций плоскочерепной полевки (A. strelzovii)

\begin{tabular}{|c|c|c|c|c|}
\hline Индекс органа & $\begin{array}{c}\text { Пол } \\
(\hat{\jmath}, \text { \&) и }(\mathrm{n}) \\
\end{array}$ & Материк & Остров & $\begin{array}{c}\text { Достоверность } \\
\text { различий (t) }\end{array}$ \\
\hline 1 & 2 & 3 & 4 & 5 \\
\hline \multirow{2}{*}{ Индекс печени } & $\widehat{\partial}\left(\mathrm{n}_{1}=22 ; \mathrm{n}_{2}=19\right)$ & $6,9 \pm 1,07$ & $4,6 \pm 0,34$ & 0,28 \\
\hline & 우 $\left(\mathrm{n}_{1}=20 ; \mathrm{n}_{2}=18\right)$ & $5,8 \pm 0,89$ & $5,9 \pm 0,35$ & 0,01 \\
\hline \multirow{2}{*}{ Индекс почки } & 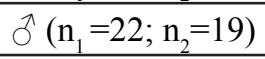 & $7,5 \pm 0,67$ & $0,55 \pm 0,065$ & 0,92 \\
\hline & $q\left(\mathrm{n}_{1}=20 ; \mathrm{n}_{2}=18\right)$ & $7,9 \pm 0,81$ & $7,8 \pm 0,09$ & 0,009 \\
\hline \multirow{2}{*}{ Индекс сердца } & $\widehat{O}\left(\mathrm{n}_{1}=22 ; \mathrm{n}_{2}=19\right)$ & $6,3 \pm 0,54$ & $0,59 \pm 0,03$ & 0,80 \\
\hline & o $\left(\mathrm{n}_{1}=20 ; \mathrm{n}_{2}=18\right)$ & $5,01 \pm 0,56$ & $5,03 \pm 0,33$ & 0,0028 \\
\hline
\end{tabular}

$\mathrm{n}_{1}$ - объем выборки из материковых популяций; $\mathrm{n}_{2}$ - объем выборки из островных популяций

Размеры сердца - хороший показатель активности животных, определяющей степень их энергетических затрат, и прежде всего на движение. Более активные, подвижные, способные переносить большие физические нагрузки и длительное мышечное напряжение виды отличаются увеличенным сердечным индексом. Изменение условий среды или образа жизни животных, требующее повышения уровня их метаболизма (энергетических затрат), как и вызывающие его биологические особенности, в том числе уменьшение размеров тела (влекущее за собой увеличение площади теплоотдачи), возрастание общей двигательной активности, понижение роста и др., приводит к увеличению размеров сердца и интенсификации его функции (табл. 6).

У особей трех видов, отловленных в материковой части впадины, сердечные индексы по сравнению с особями, отловленными на острове, многократно повышены. Особенно это правило ярко проявлено у обеих полов узкочерепной полевки, у самцов полевки-экономки (7 раз) и горной полевки (10 раз) (табл. 4-6). У самок полевки-экономки различия сердечного индекса выше у особей из материковой части незначительно (1,9 раза) по сравнению с самками из островной популяции животного. У самок горных полевок достоверных различий в двух выборках сердечного индекса не отмечается.

Использование размеров печени в качестве одного из главных морфофизиологических индикаторов основывается на ее специфической роли как энергетического (углеводного и жирового) и пластического (белкового) депо организма. Изменение печени преимущественно за счет накопления или расходования углеводов и отчасти жиров и белков позволяет судить о напряженности обменного баланса. Изменение величины печени отражает способность животных в конкретных условиях среды и в зависимости от физиологического состояния к накоплению резервных питательных веществ. При наступлении кратковременных неблагоприятных условий расходуется прежде всего резервный гликоген, а при длительном воздействии или частых повторениях - жировые запасы. По мнению многих авторов [10, 11], ведущим фактором, определяющим размеры печени позвоночных, является 
интенсивность их обмена веществ и вытекающие отсюда различия в способности поддерживать нормальную жизнедеятельность в периоды недостатка корма.

Крупные размеры печени обычно связано количеством депонируемого гликогена и прямо коррелируется с высоким уровнем основного метаболизма, характеризуется уменьшением массы тела. Такие отношения размера печени и массы тела животного может свидетельствовать о неблагоприятных кормовых условиях. Именно поэтому крупные размеры печени особей материковых популяций ставит их перед необходимостью накапливать значительные энергетические резервы.

Многочисленными исследованиями установлено, что почки более, чем какиелибо другие внутренние органы, чувствительны к изменению обмена веществ, и все условия, вызывающие интенсификацию метаболизма (в том числе уменьшение общих размеров тела, усиление активности и т. д.) сопровождаются увеличением индекса почек, поэтому данный показатель можно рассматривать в качестве масштаба обмена веществ и использовать как своеобразный индикатор уровня популяционной напряженности метаболических процессов. Справедливость такого подхода косвенно подтверждается тем, что относительные размеры почек изученных нами видов млекопитающих находятся в обратной зависимости от величины тела, что соответствует различиям в уровне обмена веществ. Особенно ясно проявляется данная закономерность у узкочерепной полевки, и у самцов полевки-экономки и горной полевки. Вполне может быть, что результаты, полученные относительно индексов почки самцов полевки-экономки и горной полевки, обусловлены небольшим объемом анализируемого материала. Возможно также, что «аномальные» показатели являются результатом закрепления некоторых вариаций интерьерных признаков и являются результатом адаптации к условиям среды. Для фиксации в генофонде подобных «морфозов» времени было достаточно со времени образования острова на морено-подпрудном озере Хиндиктиг-Холь (примерно 11-9 тыс. лет со времен последнего Вюрмского оледенения) [3].

При сравнении экстерьерных и интерьерных показателей самцов и самок полевки-экономки правило может быть нарушено. Средняя масса тела и относительные размеры интерьерных признаков самцов материковых популяций проявляют положительную корреляцию.

Исходя из приведенных данных, можно видеть, что морфофункциональные адаптации мелких млекопитающих материковых и островных популяций носят сложный и неоднозначный характер. По данным ряда авторов, в условиях техногенного пресса картина (химического загрязнения) резко меняется. Индексы сердца, почки и надпочечника имеют более высокие значения на техногенных территориях, что указывает на более интенсивный уровень метаболизма и мобилизацию внутренних резервов [24-28].

Увеличение относительных размеров изученных внутренних органов свидетельствует о повышенной нагрузке на них у материковых популяций. Возрастание метаболического процесса у животных, обитающих в материке, возможно обусловлено системой регуляторных адаптивных приспособлений организма и повышением роли органов очистки и выделения (печени, почек и сердца) в более динамичных условиях, характерного для материковой части ареала популяций видов. 
В пользу данного предположения свидетельствует проведенный биогеохимический анализ исследованной территории. Его результаты демонстрируют повышенные значения содержания некоторых химических элементов в почвенном и растительном покровах и на материке, и на острове, что, возможно, привело к изменению белково-липидного обмена у мелких млекопитающих. По данным А. А. Ревы и Е. Л. Козиной [27], изменения белково-липидного обмена выражаются в увеличении уровня белка в органах, выполняющих функцию детоксикации и выделения токсикантов из организма при одновременном снижении содержания мембранных липидов (триглециридов и холестерина). Это приводит к снижению энергетических запасов организма, а также изменяет структуру мембран клеток, что позволяет снизить проникновение в них полютантов.

Исходя из приведенных данных, можно видеть, что морфофункциональные адаптации мелких млекопитающих островных и материковых популяций носят сложный и неоднозначный характер.

Оценка биогеохимической ситуации корнеобитающем горизонте почв и надземной части растительного покрова на острове и на материке

Одна из важнейших особенностей географического положения массива Монгун-Тайга - его расположение в центре Азии и значительная удаленность от океанов (более 3500 км от Атлантического океана, более 3000 км от Индийского океана, около 2500 км от Тихого, более 2000 км от Северного Ледовитого океана). В орографическом отношении массив находится в самом центре Алтае-Саянской горной страны, юго-восточнее сочленений хребтов Горного и Монгольского Алтая и системы Танну-Ола, не относясь одновременно ни к той, ни к другой системе горных хребтов [3]. Хиндиктиг-Хольская впадина с одноименным озером на высоте над уровнем моря 2306 м находится в межгорном понижении хребтов Цаган-Щибэту с севера и северо-востока, Шапшальского с северо-запада, Чихачева с запада и юго-запада. Горный массив является зоной, охваченной периодом альпийского тектогенеза, где должно происходить усиление обмена веществом и энергией между структурными частями географической оболочки. В пределах Алтае-Саянской горной страны выделяются территории с аномально высокими концентрациями цинка, свинца, меди, кобальта, никеля, ртути, ванадия, хрома и вольфрама в компонентах экосистем - биогеохимические провинции, которые по контуру совпадают с ореолами рассеяния полиметаллических месторождений. Содержание тяжелых металлов в почвах, формирующихся в пределах биогеохимических провинций, значительно превышает верхние пороговые концентрации и ПДК. Растения характеризуются накоплением значительных количеств кобальта, меди, цинка, свинца, никеля, морфологическими отклонениями, нарушением физиологических функций [29]. Известно, что от химического элементного состава среды обитания организмов зависят их морфологическая и физиологическая изменчивость, размножение, рост и развитие [30].

Нами были проведены исследования по оценке биогеохимической ситуации почвенного и растительного покровов впадины. Сбор проб для анализа отбирались в основных биотопах обитания трех видов мелких млекопитающих - ерниковой 
горной тундре, альпинотипных лугах и остепненных склонах южной экспозиции с выходами останцовых скал в материковой части и на острове. В материковой части впадины различные типы растительности используются как летние пастбища для домашнего скота и испытывают определенный антропогенный пресс. Рыхлые, хорошо аэрируемые гумусово-аккумулятивные горизонты почв Южной Сибири могут сильно подвергаться переуплотнению при возникновении антропогенного влияния [31]. Меньшая устойчивость высокогорных остепненных почв материковой части котловины объясняется меньшим содержанием гумуса, высокой степенью их защебнённости. Растительный покров острова из-за его изолированности не испытывают антропогенной нагрузки.

В таблице 7 приведены средние значения содержания некоторых химических элементов в почве и надземной части травянистой растительности.

В тундровых почвах материковой части и на острове довольно высоки значения содержания некоторых микроэлементов из группы тяжелых металлов - ванадия, хрома, никеля, меди, цинка, свинца, превышающие в некоторых случаях ПДК элементов. При этом в надземной части растительного покрова высокие значения характерны в отношении только части вышеуказанных элементов. Высокое содержание для растительного покрова отмечается относительно цинка, свинца и, особенно, в растительном покрове материковой части, бария. Высокая аккумулирующая способность характерна для растительного покрова материковой части.

В степных почвах содержание элементов стабилизируется, значительно снижается по сравнению с тундровыми и луговыми почвами. Прямой зависимости содержания химических элементов в почве и надземной части растительного покрова степных флористических комплексов также не отмечается. Заметным явлением в данных типах растительности является заметная тенденция к аккумуляции ими некоторых элементов - бария и брома.

Из данных таблицы 7 можно заключить, что биогеохимическая ситуация в районе исследований имеет свою региональную специфику. Наблюдается многократное превышение ПДК в почвах Мn и некоторых тяжелых металлов $(\mathrm{Co}, \mathrm{Ni}, \mathrm{Cu}$, $\mathrm{Zn)}$ и на материке, и на острове. На острове в список тяжелых металлов, с превышающими ПДК значениями в почвах, добавляется и свинец $(\mathrm{Pb})$. Близкие значения в концентрациях химических элементов в почвах материковой части исследованной территории и различия в аккумулирующей способности материковых и островных ерниковых тундр свидетельствует об их различной стратегии по накоплению химических элементов. Как видно из таблицы 7, перечень элементов с высоким содержанием отличаются. На материке высокие значения среднего содержания в мохово-лишайниковом покрове имеют $\mathrm{Zn}, \mathrm{Fe}, \mathrm{Ba}, \mathrm{Pb}$ и $\mathrm{Ti}$; на острове $-\mathrm{Zn}, \mathrm{Fe}$, $\mathrm{Mn}, \mathrm{Ti}$. Возможно, биогеохимическая ситуация может и являться тем фактором, определяющим физиологическую напряженность функционирования изученных внутренних органов мелких млекопитающих. Интересно, что высокие значения микроэлементов в почвах характерны для основного корнеобитающего горизонта, что может свидетельствовать о доминировании атмосферной миграции химических элементов.

Закономерность, характерная для тундровых почв и растительности, выявляется и в почвах и растительном покрове альпинотипных лугов. 
С. О. Ондар, С. Н. Кирпотин, Н. И. Путинцев и др.

Морфофизиологическая изменчивость мелких млекопитающих Хиндиктиг-Хольской впадины

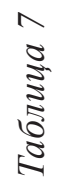

는

号

O

$+$

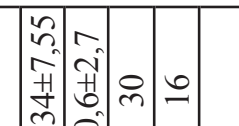

응

ती

$\infty$

응

空

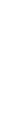

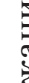

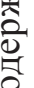

ภำ

छ

$\sum$

焉焉

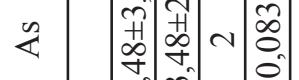

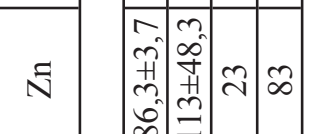
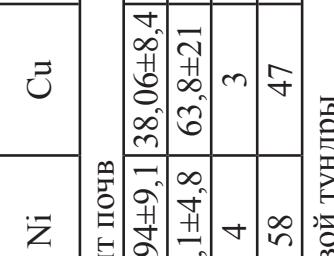

$\bar{z}$ ज्ञेते ते

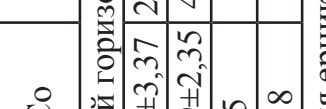

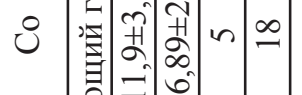

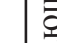

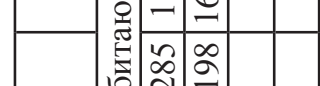

证

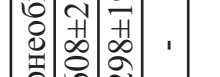

웅

文

$-$

U

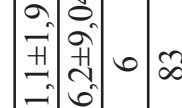

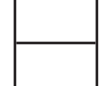

ने

$>$

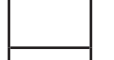

$F$

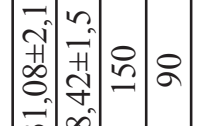

m.

กิ

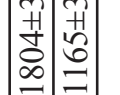

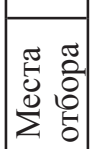

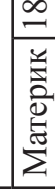

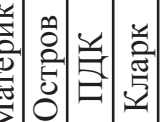

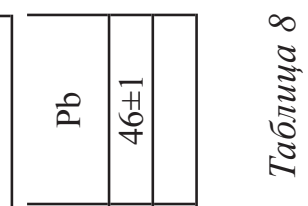

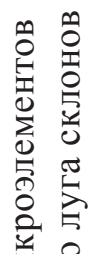

ต

๓

드

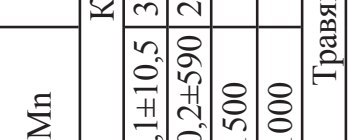
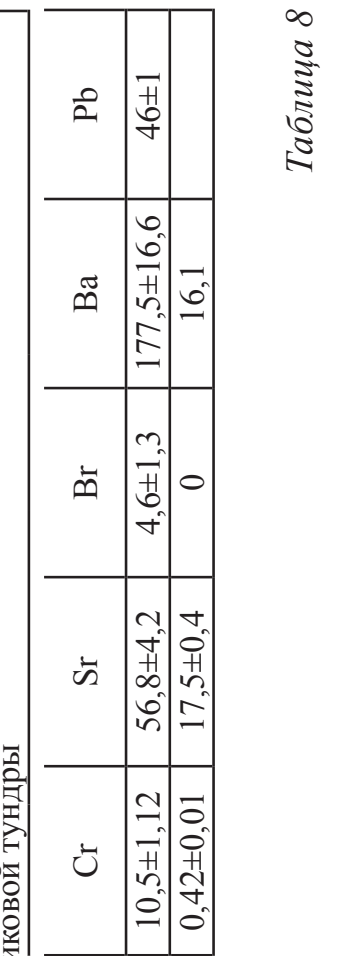

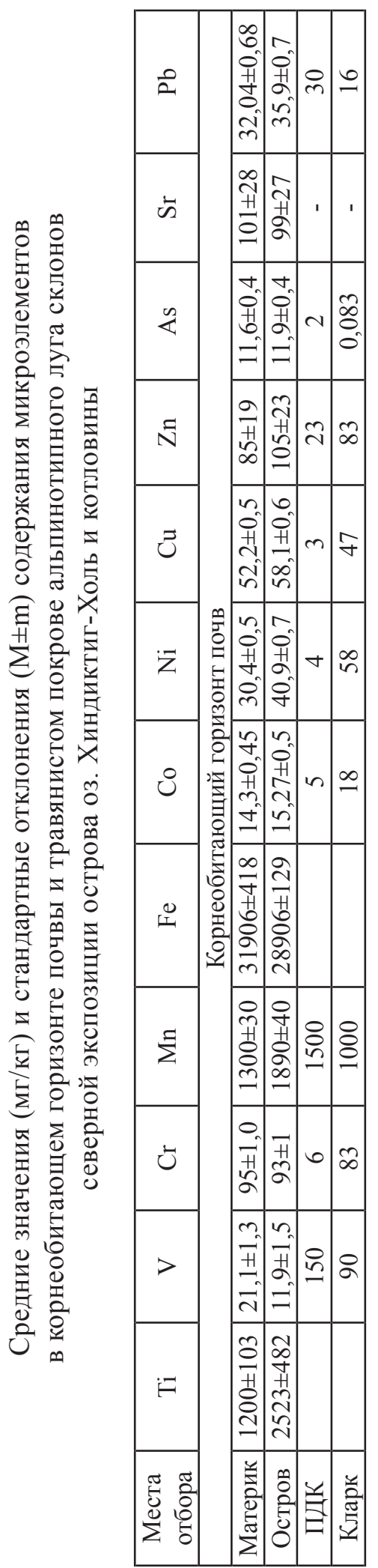


$\infty$
0
5
0
5
0
5
0
0
0
5
5
0
$\vdots$
5
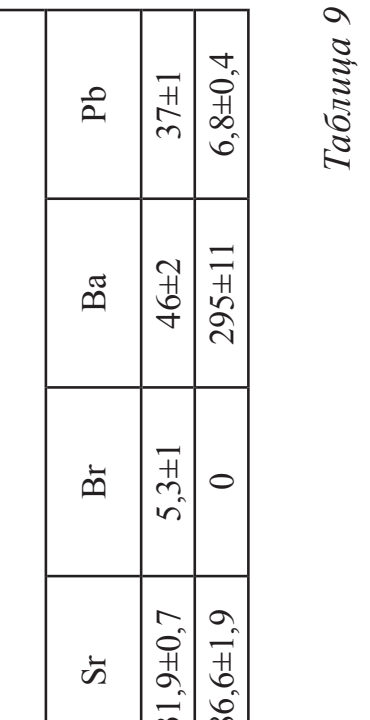

๘

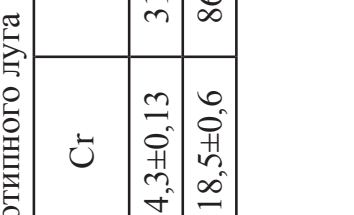

苍

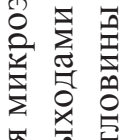

要

要,

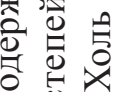

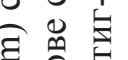

$\sum$ 茾运

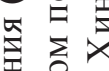

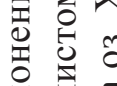

至

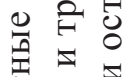

总畣

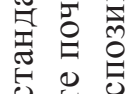

ป

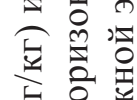

空家产

窇基

焉

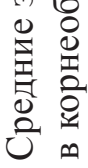

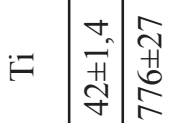

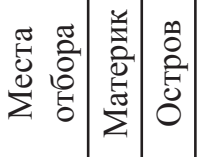

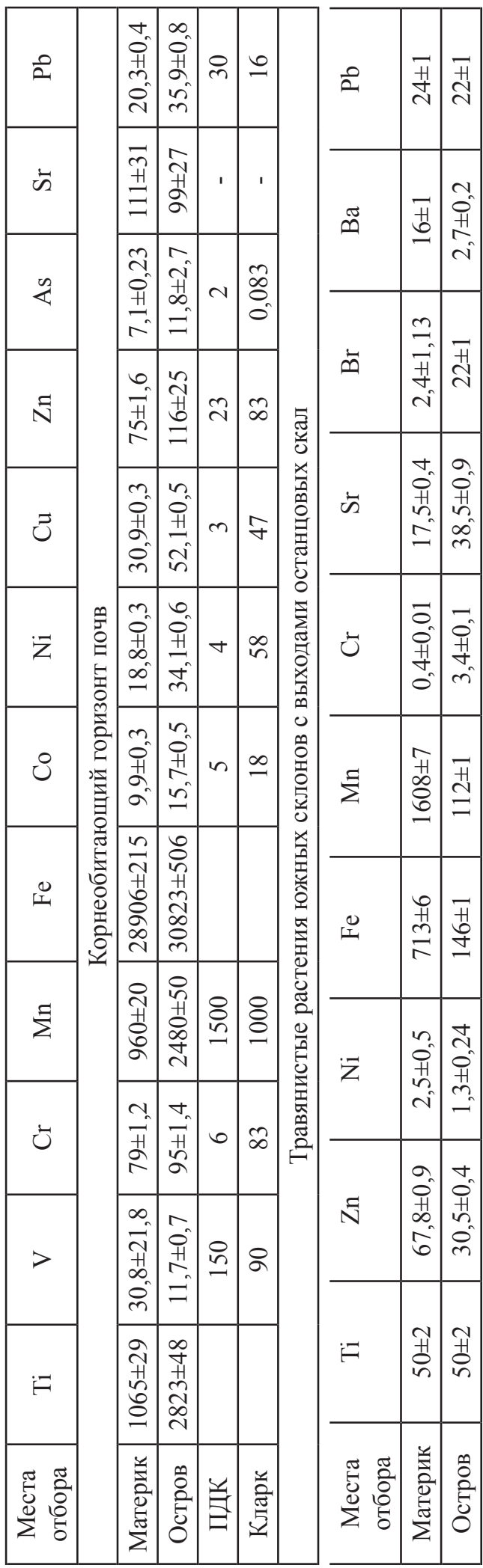

58 
Повышенные значения в надземных органах многих изученных химических элементов свидетельствует об активном их аккумуляции в растениях и включении их в биогеохимические циклы. Оценка экологического состояния растений по величине отношений $\mathrm{Fe} / \mathrm{Mn}$ и $\mathrm{Pb} / \mathrm{Mn}$ в надземных органах растений на материковой части и на острове, показало об их значительном отклонении от нормы. Так, на тундровых растительных сообществах в материковой части отношение $\mathrm{Fe} / \mathrm{Mn}$ превышает более 4-х раз, на острове наблюдается обратная картина - уменьшение от нормы в 6 раз; на альпинотипных лугах отношение $\mathrm{Fe} / \mathrm{Mn}$ на острове меньше нормы в 2 с лишним раза, на острове - превышение нормы в 9,6 раз; на остепненных биотопах материковой части наблюдается меньшие значения соотношения $\mathrm{Fe} /$ $\mathrm{Mn}$ в 0,3 раза, а на острове это отношение близко к норме $-1,3$. Отношение $\mathrm{Pb}$ / Mn на материке в среднем выше нормы в 25 раз $(0,08 ; 0,011$ и 0,015$)$, а на острове превышает более 50 раз $(0,03 ; 0,06$ и 0,19$)$, что свидетельствует о наличии специальных адаптивных механизмов у растений, формирующих стратегии выживания в условиях металлогеничной специализации района исследований.

\section{Выводы}

Сопоставление на видовом и межвидовом уровнях размеров тела и индексов внутренних органов трёх видов мелких млекопитающих Хиндиктиг-Хольской впадины показывает, что все изученные интерьерные признаки имеют видовую специфичность и в той или иной мере подтверждает известное положение о зависимости уровня основного обмена от теплоотдающей поверхности, находящейся в обратных соотношениях с массой тела. В то же время следует еще раз подчеркнуть, что прямая связь между интенсивностью метаболизма и величиной индексов, как правило, непропорциональна и неабсолютная. Более того, различные внутренние органы демонстрируют разную степень, а нередко и разный характер такой связи. Например, если индекс сердца отражает в основном степень энергетических затрат на движение и поэтому в большей степени связан с моторной активностью и сложностью движений, то индекс почек лучше других интерьерных признаков улавливает популяционную напряженность обменных процессов, а относительные размеры печени характеризуют ведущую роль этого органа в накоплении запасных питательных веществ и, следовательно, лишь косвенно связаны с общей интенсивностью обменных процессов.

Кроме того, как уже указывалось, связь интерьерных показателей с уровнем основного обмена и теплопродукцией в значительной степени затушевывается воздействием внешних и внутрипопуляционных факторов. Тем не менее, это ни в коей мере не обесценивает метод морфофизиологических индикаторов, а, напротив, расширяет сферу его применения, включая в нее экологический анализ подобных отклонений для выявления специфических реакций видов на разнообразные воздействия.

Популяции узкочерепной полевки и полевки-экономки испытывают действие определенного стресс-фактора, что приводит к изменению белково-липидного обмена организма животных на материковой части Хиндиктиг-Хольской впадины. Эти изменения проявляются в изменении экстерьерных и интерьерных морфофизиологических признаков: к снижению массы и длины тела и увеличению индексов 
внутренних органов. Можно предположить, что стресс-фактор, оказывающий влияние на популяционные показатели и морфофизиологические параметры, вызваны устойчивыми факторами физико-химического происхождения. Тенденции вариации признаков отличаются у материковых и островных популяций у узкочерепной полевки, а у горных полевок и полевок экономок общие и для материковых, и для островных популяций, хотя и проявляются в разной степени у самцов и самок. В менее ярко выраженной форме тенденция проявляется в популяциях стенотопных видов - полевки-экономки, обитателя переувлажненных лугов, а также у плоскочерепной полевки, занимающей выходы скальных пород.

Морфофизиологическую изменчивость, проявляющееся у материковых (уменьшение массы тела и увеличение индексов внутренних органов) и у островных популяций (увеличение массы тела и уменьшение индексов внутренних органов) следует рассматривать как случаи генетической ассимиляции морфозов, адаптивных к физико-химическим условиям района исследований.

\section{Литература}

1. Башенина Н. В. Пути адаптаций мышевидных грызунов. Москва : Наука, 1977. 355 с. Текст : непосредственный.

2. Булахов В. Л. К методике измерения пластических экстерьерных признаков у наземных позвоночных // Вопросы степного лесоведения. Днепропетровск : Изд-во ДГУ, 1968. Вып. 1. С. 164-166. Текст : непосредственный.

3. Демина Л. Л., Боков Д. А. Оценка эколого-морфологических параметров мелких млекопитающих в условиях техногенного воздействия // Вестник ОГУ. 2007. № 12. С. 21-26. Текст : непосредственный.

4. Земляной А. А., Суворкин М. Ю., Рева А. А. Влияние загрязнения воздушного бассейна ПО «Азот» на численность и морфофизиологические индикаторы грызунов // Ученые записки Таврического национального университета им. В. И. Вернадского. Биология. 2001. Т. 14. С. 72-75. Текст : непосредственный.

5. Земляной А. А., Шульман М. В. Морфофизиологические и биохимические адаптации Apodemus sylvaticus (Mammalia, Rodentia) к техногенной трансформации среды // Вестник Днепропетровского университета. Сер. Биология и экология. 2003. С. 167-170. Текст : непосредственный.

6. Ивантер Э. В. Опыт экологического анализа морфофизиологических особенностей мелких млекопитающих // Ученые записки Петрозаводского государственного университета. 2018. № 3(172). С. 7-12. Текст : непосредственный.

7. Изучение популяций мелких млекопитающих в условиях техногенного воздействия / Л. Е. Лукьянова, О. А. Плятова и др. // Экология. 1990. Т. 2. С. 53. Текст : непосредственный.

8. Ковальский В. В. Геохимическая экология. Москва : Наука, 1974. 300 с. Текст : непосредственный.

9. Кошелева Н. Е., Касимов Н. С., Сорокина О. И., Гунин П. Д., Бажа С. Н., ЭнхАмгалан С. Геохимия ландшафтов Улан-Батора // Известия РАН. Серия географическая. 2013. № 5. С. 111-126. Текст : непосредственный.

10. Кулижский С. П., Блохин А. Н. Использование данных о физико-химических свойствах почв юга Сибири при оценке устойчивости к внешним воздействиям // Вестник Томского государственного университета. Биология. 2009. № 3(7). С. 95-102. Текст : непосредственный. 
11. Межерин В. А., Емельянов Г. Е., Михилевич О. А. Количественные подходы в изучении популяций мелких млекопитающих. Киев : Наукова думка, 1991. С. 41-42. Текст : непосредственный.

12. Оленев Г. В. Альтернативные типы онтогенеза цикломорфных грызунов и их роль в популяционной динамике: (экологический анализ) // Экология. 2002. № 5. С. 341-350. Текст : непосредственный.

13. Оленев Г. В., Григоркина Е. Б. Метод морфофизиологических индикаторов и функционально-онтогенетический подход при решении экологических задач (на примере спленомегалии у грызунов) // Экология. 2019. № 1. С. 112-124. Текст : непосредственный.

14. Орехова Н. А. Биохимический анализ печени лесных мышей (Apodemus uralensis), отловленных в зоне Восточно-Уральского радиоактивного следа // Вестник Томского государственного университета. Биология. 2014. № 2 (26). С. 161-171.Текст : непосредственный.

15. Пузанов А. В., Ельчинова О. А. Оценка биогеохимической ситуации в АлтаеСаянской горной стране // Биогеохимия техногенеза и современные проблемы геохимической экологии : в 2 томах) (Барнаул, 24-28 августа 2015 г.). Барнаул, 2015. 326 с. Текст : непосредственный.

16. Рева А. А., Козина Е. Л. Эколого-биохимическая характеристика полевой мыши из биотопов Днепровско-Орельского заповедника и загрязненной зоны // Вестник Днепропетровского университета. Сер. Биология и экология. 1993. Вып. 1. С. 154-155. Текст : непосредственный.

17. Феоктистова Н. Ю., Найденко С. В., Суров А. В., Менгинский К. М. Эколого-физиологические особенности сезонной биологии монгольского хомячка (Allocricetulus curtatus, Allan 1940, Cricetinae, Rodentia) // Экология. 2013. № 1. С. 60-64. Текст : непосредственный.

18. Чистяков Г. В., Ганюшкин Д. А., Москаленко И. Г., Зелепукина Е. С., Амосов М. И., Волков И. В., Глебова А. Б., Гузэль Н. И., Журавлев С.А., Прудникова Т. Н., Пряхина Г. В. Горный массив Монгун-Тайга / под редакцией К. В. Чистякова. Санкт-Петербург : АртЭкспресс, 2012. 310 с. Текст : непосредственный.

19. Шварц С. С. Метод морфофизиологических индикаторов в экологии наземных позвоночных животных // Зоологический журнал. 1958. Т. 37, вып. 2. С. 161-173. Текст : непосредственный.

20. Шварц С. С., Смирнов В. С., Добринский Л. Н. Метод морфофизиологических индикаторов в экологии наземных позвоночных. Свердловск : Уральский рабочий, 1968. 386 с. Текст : непосредственный.

21. Шилов И. А. Эколого-физиологические основы популяционных отношений у животных. Москва : Изд-во МГУ, 1977. 263 с. Текст : непосредственный.

22. Шмидт-Ниельсен К. Размеры животных: почему они так важны? Москва : Мир, 1987. 259 с. Текст : непосредственный.

23. Шишкин М. А. Эволюция как эпигенетический процесс // Современная палеонтология / редакторы В. В. Меннер, В. П. Макридин. Москва : Недра, 1988. С. 142-169. Текст : непосредственный.

24. Rozhkova-Timina I. O., Zemtsov V. A., Vorobyev S. N., Kolesnichenko L. G., Loyko S. V., Kirpotin S. N. The relevance of the contemporary landscape-ecological and biogeochemical studies of the $\mathrm{Ob}$ floodplain // Вестник Томского государственного университета. Биология. 2016. № 3 (35). С. 182-200. Текст : непосредственный. Gebczynski M. Heat economy and the energy cost of growth in the bank vole during the first month of postnatal life // Acta theriol. 1975. Vol. 20. No 29. P. 379-434.

25. Kaikusalo A. Population turnover and wintering of the bank vole, Clethrionomys glareo lus (Schreb.), in southern and central Finland // Ann. zool. fenn. 1972. Vol. 9. No 4. P. 219-224. 
26. Kvasnikova Z. N., Khovalyg A. O., Dongak S. O., Dorzhu U. V. Dynamics of agricultural areas as an indicator of biodiversity monitoring in the republic of tyva // Geosfernye Issledovaniya. 2021. No. 2. P. 77-86.

27. Myrcha A. Variations in the length and weight of the alimentary tract of Clethrionomys glareolus (Schreber, 1780) // Acta theriol. 1964. Vol. 9. No. 10. P. 1-10.

28. Ondar S. O., Khovalyg A. O., Ondar U. V., Sodnam N. I. Monitoring of the state of the left-bank confluents of the Upper Yenisei basin in the zone of impact of the coal industry enterprise // International Journal of Engineering and Technology (UAE). 2018. 7(3). P. 206-214.

29. Pucek Z. Seasonal and age changes in the weight of internal organs of shrews // Acta theriol. 1965. Vol. 10. No 26. P. 369-438.

30. Selye H. The general adaptation syndrome and the diseases of adaptation // J. Clin. Endocrinol. 1946. Vol. 6. P. 117-230.

31. Wojcik J. M., Wojcik A. M., Sikorski M. D. Morphometric variation of the common shrew, Sorex araneus, in different habitats // Mammalia, 2003. T. 67. No. 2. C. 225-231.

32. Zejda J. Differential growth of three cohorts of the bank vole, Cleihrionomys glareolus Schreb., 1780 // Zook listy. 1971. Vol. 20. No 3. P. 229-245.

Статья поступила в редакцию 14.10.2021; одобрена после рецензирования 08.11.2021; принята к публикации 20.12.2021.

\section{MORPHOPHYSIOLOGICAL VARIABILITY OF SMALL MAMMALS OF THE KHINDIKTIG-KHOL DEPRESSION}

S. O. Ondar, S. N. Kirpotin, N. I. Putintsev, A. O. Khovalyg,

O. C. Oidupaa, B. S. Mongush, A. V. Kuular

Sergey O. Ondar

Dr. Sci. (Biol.), Chief Researcher,

Head of Ecological Research Laboratory,

Tuva State University

36 Lenina St., Kyzyl 667000, Russia

ondar17@yandex.ru

Sergey N. Kirpotin

Dr. Sci. (Biol.), Prof.,

Tuva State University

36 Lenina St., Kyzyl 667000, Russia

Head of «BioKlimLand» Center,

National Research Tomsk State University

36 Lenina Prospect, Tomsk 634050, Russia

kirp@mail.tsu.ru

Nikolay I. Putintsev

Junior Researcher,

Head of Ecological Museum

Tuva State University

36 Lenina St., Kyzyl 667000, Russia

bkafedra@list.ru 
Aldynay O. Khovalyg

Cand. Sci. (Geogr.), A/Prof.

of Geography and Tourism Department,

Tuva State University

36 Lenina St., Kyzyl 667000, Russia

Master's Student,

National Research Tomsk State University

36 Lenina Prospect, Tomsk 634050, Russia

aldyn@mail.ru

Orlan Ch. Oidupaa

Cand. Sci. (Biol.), A/Prof.

of Biology and Ecology Department

Tuva State University

36 Lenina St., Kyzyl 667000, Russia

baiarnasmo@mail.ru

Baylak S. Mongush

Research Assistant,

Tuva State University

36 Lenina St., Kyzyl 667000, Russia

nalro@mail.ru

Ayvar V. Kuular

Research Assistant,

Tuva Scientific Center

4 Energetikov St., Kyzyl 667000, Russia

mackenza@mail.ru

Abstract. Results of morphophysiological variability study of small mammals of HindiktigHol hollow in high mountain massif of Mongun-Taiga (South-West Tuva) are presented. A total of 224 adults of three mass species of the genus Lasiopodomus, Alexandromys (Microtus) oeconomus and Alticola were studied. Comparative characterization of exterior plastic and interior morphophysiological traits of populations of Lasiopodomus gregalis, Alexandromys oeconomus and Alticola strelzovii inhabiting identical habitats on HindiktigKhol Lake Island and on the mainland showed that complex factors and auto-regulating population mechanisms differ. Morphofunctional adaptations of small mammals of island and mainland populations are complex and ambiguous. It was established that morphophysiological parameters of species populations have variability towards decrease in mass and body length and increase in indices of internal organs on mainland, while on island populations of the same species have opposite relations - increase in mass is associated with decrease in indices of internal organs. Biogeochemical studies of soils and vegetation cover of the main biotopes of small mammals revealed high content of some heavy metals both on the island and on the mainland, which may be a factor determining the direction of adaptive capabilities of organisms. Morphophysiological variability manifested in mainland and island populations of the studied species should be considered as cases of genetic assimilation of morphoses adaptive to physical and chemical conditions of the study area. 
Keywords: Lasiopodomus gregalis, Alexandromys oeconomus, Alticola strelzovii, exterior and interior biologically signs, island and mainland populations, morphophysiological variability.

Acknowledgments. The study was supported by RFBR grant, project No. 20-67-46018 "Climatically and Anthropogenically Caused Changes in Vulnerable Ecosystems of Tuva".

For citation

Ondar S. O., Kirpotin S. N., Putintsev N. I., Khovalyg A. O., Oidupaa O. C., Mongush B. S., Kuular A. V. Morphophysiological Variability of Small Mammals of the Khindiktig-Khol Depression. Nature of Inner Asia. 2021; 4(19): 45-64 (In Russ.).

DOI: $10.18101 / 2542-0623-2021-4-45-64$

The article was submitted 14.10.2021; approved after reviewing 08.11.2021; accepted for publication 20.12.2021. 